\title{
Market Size and Concentration: Insurance and the European Internal Market 1992*
}

\author{
by Roland Eisen **
}

\section{Introduction}

The goal of the ongoing endeavours within the European Community under the Single European Act is the creation of a single European market or an internal market. It embraces the total territory of the EC, i. e. approximately 2.95 million square kilometers, a population of 324 million, and a gross EC product of 4,274 billion US- $\$$. In comparison, the U.S. A. is three times as large, embraces a population of 244 million, and has a gross national product of 4,502 billion US- $\$$. To complete this comparison, see also the figures for Japan, given in Table 1.

Table 1:

A Comparison between EC, U.S.A. and Japan

\begin{tabular}{|c|c|c|c|c|}
\hline Country & $\begin{array}{c}\text { Population } \\
\text { (million) }\end{array}$ & $\begin{array}{c}\text { Gross Nat. } \\
\text { Product (billion) }\end{array}$ & $\begin{array}{c}\text { GNP/ } \\
\text { capita }\end{array}$ & $\begin{array}{c}\text { Insurance premia } \\
\text { as \% of GNP }\end{array}$ \\
\hline EC & 324 & 4,274 & 13,200 & 6.0 \\
U.S.A. & 244 & 4,502 & 18,500 & 9.1 \\
Japan & 122 & 2,387 & 19,600 & 8.8 \\
\hline
\end{tabular}

It is the aim of the EC to create in stages a framework for a free and competitive internal market for financial scrvices (banking, insurance etc.) by the year 1992. Therefore, four years ago (in July 1986) the heads of the state and government of the EC countries decided to creatc a single economic arca in which goods, labour, scrvices, money and capital could

* Paper presented at the 17th Seminar of the European Group of Risk and Insurance Economists, September 17-19, 1990, Vienna. An earlier version was presented at the Industrial Economics Seminar of the UCSB, and at the Insurance and Risk Scminar of the Wharton School, University of Pennsylvania. The comments provided by the seminar participants, especially Bill Comanor, David Cummins. Ted Frech III, Jean F. Outreville, Mark Pauly, and Peter Zweifel are gratefully acknowledged. Nevertheless, the usual caveat applies. I would like to thank Ilonka Rühle for her competent research assistance. The research was supported in part by a DFG travelling grant.

** Department of Economics. I.-W. Goethe University. D-6000) Frankfurt. 
move freely. But, regarding this objective, it must be added that there will be no integrated, fully harmonized market. Whereas until 1985 the concept of harmonization was closely adhered to, since the passing of the EC White Paper (Commission, 1985) the aim is "mutual recognition". This means, there will be no attempt to impose community wide rules beyond a core of essential regulations and standards by means of EC directives. But mutual recognition will not be an end in itself. The assumption is that mutual recognition will lead to regulatory convergence through "competition of systems". Accordingly, the most efficient regulatory system would ultimately determine the overall European regulations and standards.

The way to the internal market is increasing liberalization of the highly regulated and segregated markets, and releasing competitive forces. This will be achieved by a legislative program which is aimed at stimulating cross-border transactions and encouraging investments and establishments in foreign territories.

The beginning of this process of liberalization in insurance dates back to the First NonLife Coordination Directive of 1973 (Doc. No. 73/239/EEC) which regulated the freedom of establishing firms, i. e. the right of firms to set up a subsidiary or agency under the same requirements that apply to domestic firms. Having realized the freedom of establishment, the freedom of services lies at the core of the internal market program for insurance.

In recent years, this process has been influenced essentially by two decisions of the European Court of Justice. First, the decision of December 4, 1986 relating to the freedom to provide services, and second the decision of January 27, 1987 relating to the EC cartell law. In the first decision the European Court stated that the freedom of services follows directly form the Rome Treaty, but the Court allowed member states to restrict this freedom to protect consumers. This leads - strictly speaking - to a bifurcation of the insurance market, on one side large risks, on the other side mass risks, where a special need is given to protect the insured. In the second decision the Court declared some non-binding recommendations regarding premium adjustments as invalid and against the EC Treaty $(\S 85)$. This means: The insurance market is no longer automatically an "exempted sector" with reference to the anticartel laws.

The current state of the EC directives on freedom of establishment and freedom of services can be seen from the summary in Table 2 . Special attention should be called to the Second Non-Life Coordination Directive (Doc. No. 88/357/EEC) and the proposal for the Second Life Coordination Directive (Doc. No. 89/C38/08).

In the following the likely effects of these measures on the insurance market will be discussed along the following lines: In the next section a general assessment of the likely effects is given - increases in the size of the market and in the degree of competition -, and the central hypothesis is developed, namely the relationship between market size and firm size. In the third section causes for increasing returns to scale and scope in the insurance industry are discussed. Since the forces to generate increasing returns to scale and scope vanish rapidly, the notion of a minimum efficient firm size (MES) is problematic. Thus, to test the proposed hypothesis between market size and firm size, different approaches to quantify the MES are analysed. Given these results, the hypothesis is tested in the fourth section. Some remarks regarding the likely future of the European Single Insurance Market conclude the paper. 
Table 2:

Community Measures in the Field of Insurance

\begin{tabular}{|c|c|c|}
\hline INSURANCE BRANCH & DATE OF ADOPTION & DOC. NO. \\
\hline \multicolumn{3}{|c|}{ I. Directives on Freedom of Establishment } \\
\hline \multicolumn{3}{|c|}{$\begin{array}{l}\text { (Abolition of restrictions on freedom of establisment and freedom to provide services } \\
\text { in respect to reinsurance and retrocession). }\end{array}$} \\
\hline $\begin{array}{l}\text { Non-Life Insurance } \\
\text { (First Non-Life Coordination } \\
\text { Directive) } \\
\text { (Abolition of restrictions on free } \\
\text { insurance other than life insuran }\end{array}$ & $\begin{array}{l}\text { 24. } 7.1973 \\
\text { blishment in the busines }\end{array}$ & $\begin{array}{l}\text { 73/239/EEC } \\
73 / 240 / \mathrm{EEC} \\
\text { of direct }\end{array}$ \\
\hline Insurance Intermediaries & 13. 12.1976 & 77/92/EEC \\
\hline $\begin{array}{l}\text { Life Insurance } \\
\text { (First Life Coordination } \\
\text { Directive) } \\
\text { (Coordination of laws, regulatior } \\
\text { taking up and permit of business }\end{array}$ & $\begin{array}{l}\text { 5. } 3.1979 \\
\text { inistrative provisions rel } \\
\text { insurance) }\end{array}$ & $\begin{array}{l}79 / 267 / \mathrm{EEC} \\
\text { ing to the }\end{array}$ \\
\hline $\begin{array}{l}\text { Non-Life Insurance } \\
\text { Amendments }\end{array}$ & $\begin{array}{l}10.12 .1984 \\
22.6 .1987\end{array}$ & $\begin{array}{l}84 / 641 / \mathrm{EEC} \\
87 / 343 / \mathrm{EEC} \\
87 / 344 / \mathrm{EEC}\end{array}$ \\
\hline \multicolumn{3}{|c|}{ II. Directives of Freedom of Services } \\
\hline Reinsurance & 25.2 .1964 & $64 / 225 / \mathrm{EEC}$ \\
\hline Insurance Intermediaries & 13. 12.1976 & 77/92/EEC \\
\hline Coinsurance & 30. 5.1978 & 78/473/EEC \\
\hline $\begin{array}{l}\text { Non-Life Direct Insurance } \\
\text { (Second Non-Life Coordination } \\
\text { Directive) } \\
\text { (Freedom to provide services in }\end{array}$ & $\begin{array}{l}\text { 22. } 6.1988 \\
\text { ife insurance, large risk }\end{array}$ & $88 / 357 / \mathrm{EEC}$ \\
\hline $\begin{array}{l}\text { Life Direct Insurance } \\
\text { (Second Life Coordination } \\
\text { Directive) }\end{array}$ & $\begin{array}{l}\text { Proposal of } \\
23.12 .1988\end{array}$ & $89 / \mathrm{C} 38 / 08$ \\
\hline Motor Insurance & $\begin{array}{l}\text { Proposal of } \\
\text { 3. 1. } 1989\end{array}$ & $89 / \mathrm{C} 65 / 06$ \\
\hline
\end{tabular}

Sources: EC-Commission, Directorate for Financial Institution; Sigma 1/90: EC 92 - On the way to a Common Insurance Market. 


\section{The likely effects of the liberalization program}

Many of the initiatives currently enacted or under active discussion will increase the size of the market that firms operate in. Furthermore, many of the enacted or proposed policy initiatives will have an effect on the degree of competition in and between markets. Thus, the primary effects of reducing intra-community trade barriers through liberalization will be an increase in market size and in the degree of competition in the newly enlarged market.

The likely effects of increasing market size and the degree of competition relate first to static efficiency. As market size increases, whatever limitations that demand may have formerly put upon the realization of scale economies are removed, and firms will be able to move further down their average costs curves. Increases in the degree of competition in markets are likely to encourage firms to reduce levels of X-inefficiency. These two effects movements along a declining cost curve and movements between cost curves - clearly reinforce each other, and lead to an unambigous prediction that costs are likely to fall as market size and the degree of competition increase. Furthermore, the opening of borders will lead to a diminishing of national price differences for insurance services currently observable.

These effects on static efficiency are straightforward; less clear are the likely effects on dynamic efficiency, i.e. the introduction of new products, new qualities of existing products, new production methods and so on. ${ }^{1}$

There are, therefore, four main possible sources of economic gains arising from the adoption of the Internal Market Program for insurance:

- increased production levels due to the better exploitation of economies of scale and scope made possible by the increase in the size of the market;

- changes in economic efficiency brought about by increased competition;

- increased specialization in accordance with the law of comparative advantage:

- and, last but not least, changes in dynamic efficiency or innovativeness.

It is not my intention to trace all these effects and economic gains, and to estimate them in money's worth. This was done by a large group of researchers (cf. Emerson et al., 1988), and - for the insurance and banking industry - by Price Waterhouse, International Economic Consultants. They estimated the gains in consumer surplus from European Economic Integration for the total sector of financial services in the range of 11-33 billion ECUs, the midpoint estimate is given with 21,6 billion ECUs (cf. Price Waterhouse, 1988).

A starting point of the research was that there are large observed differences in firms' share of different national markets, the share of home firms typically being very much larger than that of foreign firms - even in those countries with low legal market entrance barriers as e.g. the Netherlands and Great Britain. These differences in market share may be the result of three factors:

- non-tariff trade barriers such as differences in national regulations;

- differences in distribution networks and - hence - in transaction costs;

- and consumer preference patterns and information barriers.

1 For the relationship between an increase in market size and innovativeness, see P. A. Geroski (1988). Some arguments relating to insurance can be found in Eisen/Müller/Zweifel (1990 a). 
These regulatory and market barriers to trade result in different prices being charge in the different countries. Furthermore, it is without doubt "that higher regulated insurance prices do stimulate additional non-price competition rather than higher profits", as Frech/ Samprone (1980, p. 433) remark. Nevertheless, in order to give a quantitative assessment of the likely effects of completing the internal market in financial services, Price Waterhouse used price differences of spccific products and services "in such a way as to attempt to minimise these factors" (op. cit., p. 11): The estimates "are bascd primarily on assumptions of the likely movement of prices in an integrated financial market " (op. cit., p. 19). Even if these estimatcs arc somewhat tcntative and qucstionable, the figures reinforce the impression that the current process of liberialization may lcad to a surprisingly large gain in economic efficiency.

In order to rcalizc thcse gains in cconomic efficicncy the insurance industry has to change. However, in which way the insurance industry will respond to the development of the internal market? The forms which these responses may take are not intuitively obvious. But one way to cope with this question is to consider likely changes in industry's structure.

The two most significant results emerging from different studies relating to changes of industrial structure are, first, that domestic market size has an important effect on plant or firm sizes. Second, the enlargement of an industry's market through trade allows the scale of an industry's typical operating unit to increase (cf. Scherer et al., 1975).

These two findings taken together suggest that the economic climate created by the liberalization program will pull up the size of the representative firm in the EC insurance market, and will lead to an intensified interest in cross - border acquisitions and merger opportunities. In the period between 1984/85 and 1986/87 alone take-overs and mergers in the banking and insurance sector almost doubled (see Figure 1).

Figure 1: Mergers and Take-overs in Banking and Insurance

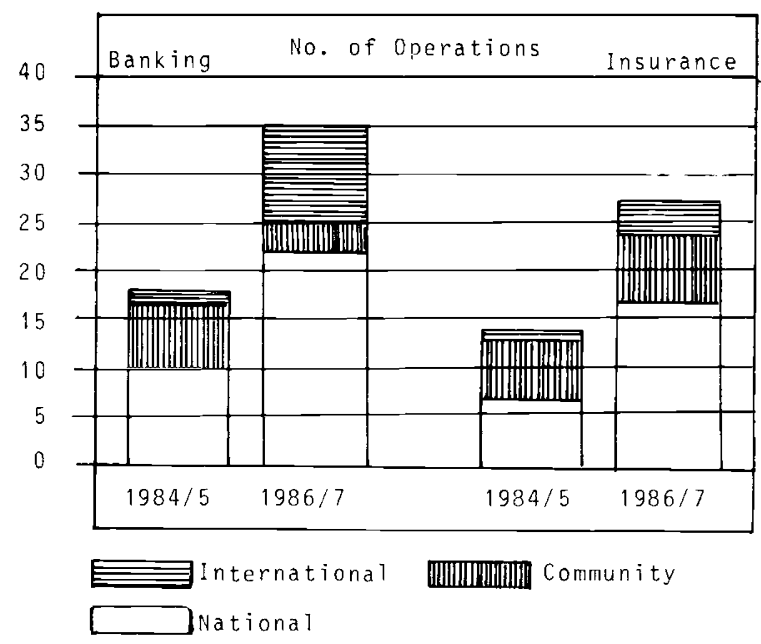

Source: EC-Commission, Report No. 17, Competition Policy, Brussels 1988, p. 240. 
Though these were predominately national operations, international mergers and cooperations are also increasing (see The Economist 314 [No. 7643, Febr. 24, 1990], pp. $15-20$ ).

In the following the likely effects of the European Internal Market on the insurance industry will be estimated especially with regard to the relationship between market size and firm size.

\section{Theoretical arguments for minimum efficient firms}

Before testing the hypothesis relating firm size to market size I want to discuss some theoretical issues. First, are there increasing returns to scale and scope in insurance? If yes, to what extent? Second, given the results of the first question, what conclusions can be drawn for the optimal size of the insurance firm? And, related to this question, why can so many small insurance firms survive?

To answer these questions I present first some theoretical arguments in favour of increasing returns to scale and scope. Second, some empirical evidence as regards to increasing returns is presented. In the third step I analyze the problem of the optimal size of the insurance firm or the minimum efficient scale of the insurance firm.

The basis for evaluating the arguments in favour of increasing returns is a description of the components of the "service production potential" of insurance firms. The production of insurance services depends not only upon technical-organizational capacity, the so-called "service potential", but depends also upon the financial capacity or "risk potential". Following the traditional arguments - according to the law of large numbers - the variance of the total risk diminishes proportionally with the number of the combined (almost independently distributed) individual risks. Using certain principles of premium calculation there results a declining risk premium.

Second, there may exist economies of scope resulting from the simultaneous production of many services. It follows then that the total production costs are smaller than the costs of producing the services one by one. I have in mind especially using the same information basis for many different services. But these economies vary in general with the output combination. The simple concept of average cost is no longer sufficient to deal with the problems of multi-service firms (cf. Baumol et al., 1982).

At the third place we have to consider economies of scale and scope in the pure service branch or the technical-organizational branch. Besides pure organizational and teclinical innovations (computer hard- and software, learning by doing etc.) there are transactions costs (cf. Marshall, 1974). Pari passu with firm size not only do "risk costs" decline but also the transactions costs per individual risk. There are, however, peculiarities in transactions costs, selling and supervisory costs so that opinions differ regarding the development of these pure service costs.

Related to this problem are the questions of how far different distribution systems affect the development of average costs, and whether there are systematic cost differences between stock companies and mutual insurers. On one hand, it seems easy to answer the question of the influence of different distribution systems: direct under-writing (i.e. without agents) is cheaper than using agents, but opinions differ whether multi-firm agents are cheaper than single-firm agents (see the evidence in Cummins/Vanderhei, 1979, and Zweifel/Ghermi. 
1990). On the other hand, there seems to exist a correlation between the legal structure of the company and the way they distribute their products (see e.g. Finsinger, 1983, pp. 81 sqq. and pp. 113 sqq., and Frech, 1990).

Summarizing these arguments, it is very likely that there are economies of scale and scope within a certain range of output. However, it seems controversial whether - beyond a certain point - these economies remain or diminish or whether long run average costs will rise at higher output levels. This ambiguity is shown in Figure 2 with the help of three different shapes of long-run average cost curves.

Figure 2:

\section{Long-Run Average Cost Curves ( $L A C$ )} and Minimum Efficient Size (MES)

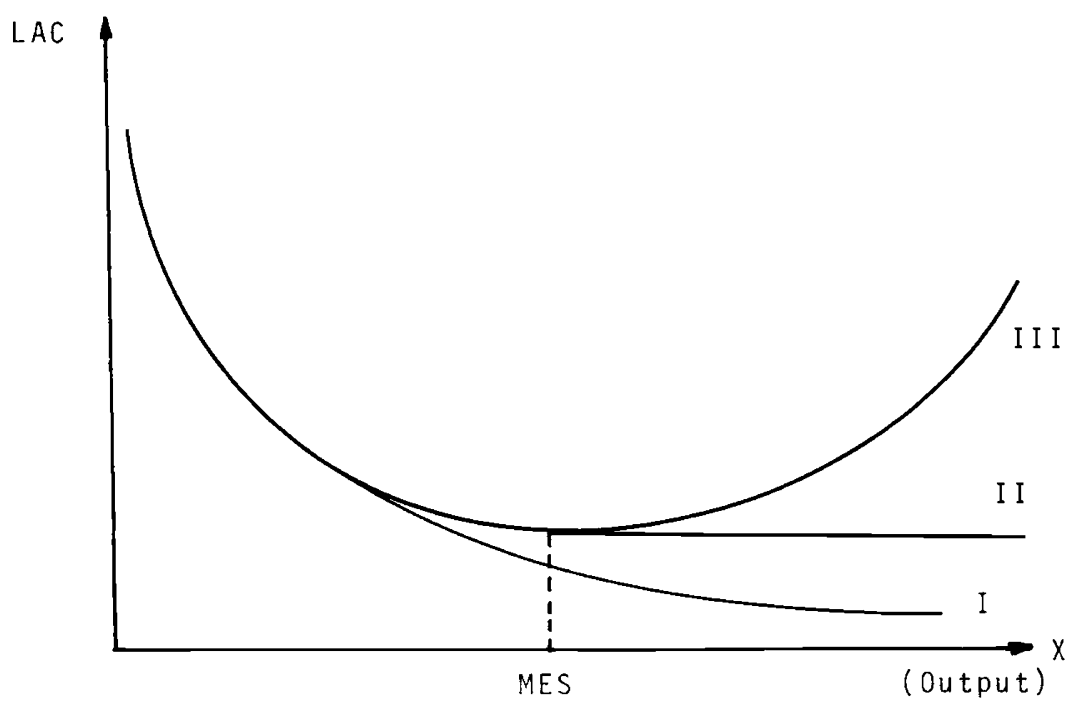

At least, only an empirical analysis can give a decisive answer relating to the likely development of (long run) average cost curves. In the literature, however, there exists a heated debate on how to measure output. Alternatives are total premium income, premium income net of reinsurance, losses (net of reinsurance) incurred by the firm, the number of insurance contracts, or an index of the different activities of an insurance company. It seems to me that total premium income may provide a sensible weighed measure of a heterogeneous vector of outputs - as long as competition is not too bad (cf. Doherty, 1981). A second problem relates to the type of function chosen. Alternatives e.g. are linear, quadratic or logarithmic functions.

Figure 3 shows the result of a linear regression between the expense ratio (i. e. ratio of expenses to premium income net of reinsurance) against the logarithm of premium income for the German life insurance industry. The regression line is falling pointing to 
increasing returns to scale. There exists, however, quite a lot of publications on this subject, ${ }^{2}$ and the empirical evidence is inconclusive. Furthermore, if price competition is almost completely excluded - as in the case of the German life insurance industry via premium regulation - most effects of competition will appear as quality differences which are not measured. Braeutigam/Pauly (1986) explore the implications of endogenous product quality in the empirical estimation of cost functions. They show "that such an omission can seriously bias estimates of economically important parameters, for example, measures of scale economies... Accordingly, conventional estimates of the effects of scale... could well be misleading" (pp. 616/7).

Figure 3:

Long-run Cost Curve, German Life Insurance, 1987

(Expence Ratio $=a-b \cdot \log$ Net Premium)

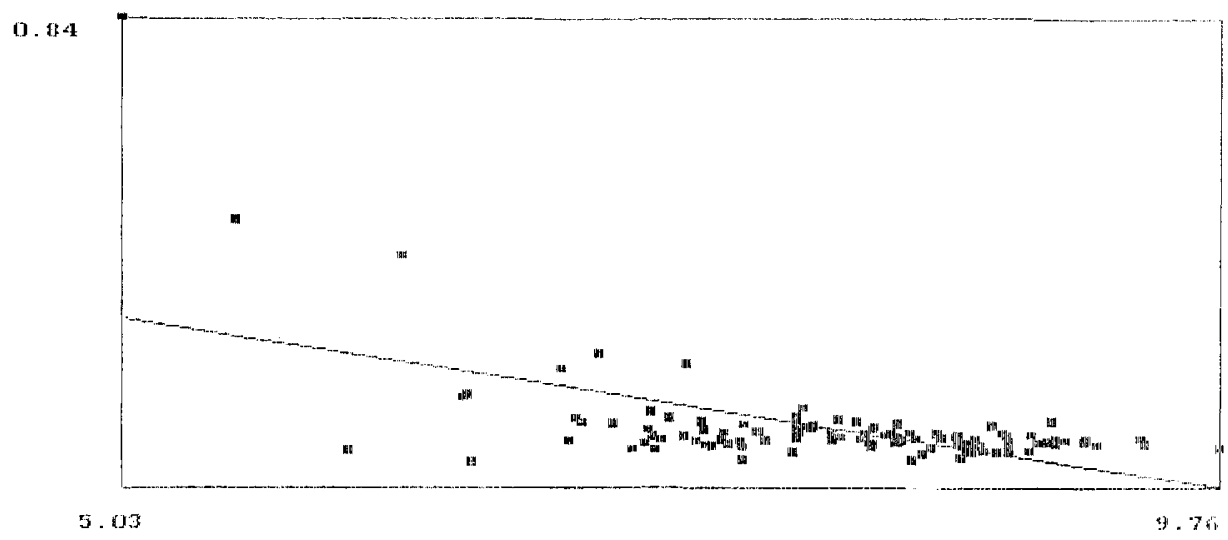

In addition, overall economies of scale are incompatible with the evidence that in insurance markets there is a large number of independent firms of vastly different sizes (see Figure 3 for an illustration of the size distribution). However, to measure the importance of scale economies one needs the concept of the minimum efficient size (MES) of the firm, and has to relate this concept to the total capacity or output of the insurance industry. But as the empirical evidence regarding scale economies is inconclusive, and therefore, there is no exact (cost based) measure of MES, use is made here of different methods to measure the MES to mitigate disagreement over the appropriate measure of the optimum size of firm. It has become customary to use proxies based on the size distribution of firms (or plants) in the industry:

a.) Pashigian (1969) and others have utilized the average firm size as an indicator of MES. Henceforth this measure will be called MES 1.

${ }^{2}$ For a recent survey of the literature, see Pestieau/Pirard (1989). 
b.) An alternative measurc is the "Midpoint (plant or) firm size" index developed by Weiss (1963). This index "estimates the employment or output of that individual plant which is located at the 50 percent point of the cumulative size distribution" (Scherer et al., 1975, p. 66). This is known, more generally, as the median of the first moment distribution. This measure will be called $\mathrm{MES}_{2}$.

c.) A third measure has becn proposed by Comanor/Wilson (1967), the so-called "Top 50 Percent" index, henceforth MES 3 . This index takes "the average plant size amongst the largest plants accounting for $50 \%$ of industry output". It is "found by moving down the plant size distribution starting with the largest plants, until enough plants have been included to encompass 50 percent of total industry employment or output. The average plant size of those plants which account for the top half of the cumulative output size destribution is then calculated" (Scherer et al., 1975, p. 66).

Since the implicit assumption behind the Weiss proxy is that in all industries exactly $50 \%$ of output is supplied by firms operating at suboptimal scales, and MES $2<\mathrm{MES}_{3}$, both proxies will typically overstate "true" MES. This is so because many previous studies of suboptimal firms suggest a much lower figure as typical (cf. Davies, 1980, p. 291 and p. 296) - namely a mean value of around $30 \%$ with standard deviation of $13-18 \%$. This implies that the measurement error incurred when using $\mathrm{MES}_{2}$ or $\mathrm{MES}_{3}$ will be the larger the greater is the variance of size within the efficient set.

Therefore one should propose a "safe criterion" to use as a fourth proxy. As such, perhaps the survivor technique is still a leading candidate for future empirical work. ${ }^{3}$ This may be justified, because Weiss (1964) found a negative relationship between the concentration ratio and the share of output of firms of suboptimal size. ${ }^{4}$ Still another approach to measure the MES of insurance firms was suggested by Outreville (1987). He uses the Herfindahl concentration index and calculates the "equivalent number" of firms. The "equivalent number" is that number of firms of the same size which could exist on the market without changing the degree of concentration. But, the Herfindahl-Index is one out of several indices, and in the present state of the art there is no logical basis for choosing between different measures of concentration.

There exists a well-defined MES if cost curves are u-shaped. An increase in demand then implies entry of (new) firms. But if economies of scale and scope exist only for a relatively small range of output this seems to indicate that beyond the MES (long-run) average costs are constant. An increase in demand could then be satisfied by the existing firms because the behaviour of unit costs does not restrict the size of the firm (see also Pashigian, 1969 , p. 293). Nevertheless, what remains to be explained is the size of the suboptimal sector, which is determined partly by technology (i.e. the shape of the cost curve at suboptimal outputs) and partly by othcr factors. The cxistence and survival of suboptimal firms give rise to the conjecture that - in the medium run - industry price exceeds minimum costs, and this in turn suggests non-trivial cntry-barriers (although this depends on the

\footnotetext{
${ }^{3}$ Large practical difficulties and the lack of data prevented the use of this technique here. although it seems more appropriate to the insurance industry than "engineering estimates". But see $D$. Appel et al. (1985).

${ }_{4}$ Weiss (1964) infered that industries with low concentration were less efficient because a larger share of their output was produced at suboptimal output levels.
} 
shape of the cost curve, too; cf. Davies and Lyons, 1982, p. 910). Therefore, a great part of the growing new demand will be served by the existing firms, a (smaller) part by new entrants or diversifying old firms.

Another explanation relies on asymmetric information between insured and insurer, differing search costs and/or different price elasticities of demand of consumers. Futhermore, small insurers may be specialists in only one line or serving only restricted groups of insured.

\section{Firm size and market size: an empirical analysis}

As mentioned in the beginning, the main interest of this paper lies in estimating the likely effects of the Commission's program of liberalization of insurance markets on the market structure. After having discussed different concepts of MES, the central hypothesis regarding the relationship between market size and firm size will be tested, thereby proceeding in three steps. First, different values of MES for 11 countries are estimated. Second, the relationship between different MES and the market size of these countries is evaluated. Third, the correlation between the number of insurance firms and market size in different countries are estimated. For the test use is made of data for six EC countries, U.S.A., Japan, Canada, Switzerland and Austria. ${ }^{5}$

First, different MES of insurance firms using the proposed alternative measures are calculated. The results are shown in Tables 3 and 4 for life and non-life insurance, respectively.

Table 3: MES (different measures), life insurance in 1987 (in million US-\$)

\begin{tabular}{|l|r|r|r|r|r|}
\hline \multirow{2}{*}{ Country/No. } & \multirow{2}{*}{ MES 1} & \multirow{2}{*}{ MES 2} & \multicolumn{2}{|c|}{ MES 3 } & \multicolumn{2}{|c|}{ Ratio } \\
& & & & & \\
& & & & & \\
& & & & & \\
USA $^{2}$ 2265 & 102.75 & 1326.0 & 3084.9 & 2.91 & 30.02 \\
Japan 40 & 4457.79 & 11383.6 & 21789.2 & 2.56 & 5.56 \\
Germany 106 & 299.83 & 653.7 & 1226.3 & 2.18 & 4.09 \\
Great B. 281 & 169.21 & 1232.3 & 2147.8 & 7.29 & 12.70 \\
Frince 9 & 157.70 & 799.1 & 1506.5 & 5.07 & 9.56 \\
Canada & - & 181.9 & 292.9 & - & - \\
Italy 56 & 76.32 & 515.7 & 728.8 & 6.76 & 9.55 \\
Netherlands 193 & 56.30 & 415.6 & 703.8 & 7.39 & 12.50 \\
Switzerland 16 & 341.12 & 1037.6 & 1734.9 & 3.05 & 5.09 \\
Spain 125 & 33.38 & 301.8 & 779.5 & 9.05 & 23.36 \\
Austria 35 & 55.27 & 131.5 & 213.6 & 2.38 & 3.87 \\
\hline
\end{tabular}

$1986 \quad 2$ Life / Health

The first column gives the country and the total number of insurance firms in that country. The next three columns give the alternative measures of the MES : average firms size $\left(M_{1} S_{1}\right)$, the midpoint firm size index $\left(M_{2} S_{2}\right)$, and the top fifty percent index $\left(M^{2} S_{3}\right)$. The last two columns show the deviation of $\mathrm{MES}_{2}$ and $\mathrm{MES}_{3}$ from the average firm size (MES 1 ),

5 The original data base was a similar study at the Swiss Reinsurance Company (cf. Swiss Rc. 1989). 
Table 4: MES (different measures), non-life insurance in 1987 (in million US-\$)

\begin{tabular}{|c|c|c|c|c|c|}
\hline Country/No. & $\operatorname{MES}_{1}$ & $\mathrm{MES}_{2}$ & $\mathrm{MES}_{3}$ & \multicolumn{2}{|c|}{$\frac{\text { Ratio }}{\mathrm{MES}_{2} / \mathrm{MES}_{1} \mathrm{MES}_{3} / \mathrm{MES}_{1}}$} \\
\hline USA' 3799 & 51.03 & 2955.2 & 6145.1 & 57.91 & 120.42 \\
\hline Japan 58 & 1082.53 & 4162.5 & 6599.22 & 3.85 & 6.10 \\
\hline Germany 342 & 104.01 & 520.0 & 1041.05 & 5.00 & 10.01 \\
\hline Great B. 626 & 58.97 & 3724.9 & 4054.70 & 63.17 & 68.76 \\
\hline France 2352 & 71.42 & 687.8 & 1151.32 & 9.63 & 16.12 \\
\hline Canada & - & 234.5 & 307.10 & - & - \\
\hline Italy 181 & 85.64 & 269.2 & 665.60 & 3.15 & 7.78 \\
\hline Netherlands 2370 & 19.82 & 146.7 & 282.74 & 7.41 & 14.27 \\
\hline Switzerland 84 & 84.83 & 675.6 & 906.68 & 7.97 & 10.69 \\
\hline Spain 327 & 20.46 & - & $\ldots$ & - & - \\
\hline Austria $^{3} 60$ & 58.79 & 283.4 & 394.62 & 4.82 & 6.72 \\
\hline
\end{tabular}

'Property/casuality $\quad 21986 \quad{ }^{3}$ without health insurance

measured as ratios. These ratios between average firm size and MES should reveal whether firms are large enough to realize all efficiency gains. It is interesting to see that especially the relatively "open" insurance markets of the United States, Spain, Great Britain and the Netherlands show the greatest deviations indicating that there may be too many "inefficient" insurance companies. Furthermore, the deviations of the minimum efficient firm size in non-life insurance are generally larger than in life insurance. The figures for Great Britain and United States are astonishing large. The means and standard deviations of the different variables are listed in Table 5 .

Table 5: Means and Standard Deviations

\begin{tabular}{|lr|r|r|}
\hline Variables* $^{*}$ & Mean & Standard Deviation \\
\hline S (market size) & $\mathrm{L}$ & $48,034.09$ & $79,950.98$ \\
MES 1 & $\mathrm{NL}$ & $36,682.27$ & $55,198.97$ \\
& $\mathrm{~L}$ & 569.97 & $1,369.48$ \\
MES 2 & $\mathrm{NL}$ & 163.75 & 323.96 \\
& $\mathrm{~L}$ & $2,001.08$ & $4,467.96$ \\
MES $_{3}$ & $\mathrm{NL}$ & $1,365.98$ & $1,588.31$ \\
& $\mathrm{~L}$ & $3,382.57$ & $7,150.69$ \\
S/MES & $\mathrm{NL}$ & $2,154.81$ & $2,479.35$ \\
& $\mathrm{~L}$ & 311.1 & 690.56 \\
S/MES 2 & $\mathrm{NL}$ & 619.8 & $1,131.03$ \\
& $\mathrm{~L}$ & 33.15 & 46.23 \\
S/MES 3 & $\mathrm{NL}$ & 36.49 & 22.17 \\
& $\mathrm{~L}$ & 16.61 & 20.43 \\
& $\mathrm{NL}$ & 20.17 & 9.88 \\
\hline
\end{tabular}

*Dollar amounts are in millions; $\quad \mathbf{L}=$ Life. $\quad \mathrm{NL}_{2}=$ Non-Life insurance. 
The ratio S/MES 1 (where $S$ is market size) represents the "optimal" number of firms in each market (according to the chosen MES criterion). The reciprocal of $S / M E S_{1}(i=2,3)$ represents the market share of a firm of minimum efficient size. A (fivefold) multiple of this reciprocal is an estimate of the minimum efficient concentration ratio (MECR) which can be compared with the actual (five firm) concentration ratios. The results of this comparison are shown in Table 6.

Table 6:

Actual Concentration Ratios (CRs) and Minimum Efficient Concentration Ratios (MECR)

\begin{tabular}{|lr|r|}
\hline Variables & & Mean \\
\hline CR5 & L & 10.12 \\
& NL & 7.41 \\
MECR2 & L & 0.32 \\
& NL & 0.23 \\
MECR3 & L & 0.55 \\
& NL & 0.34 \\
\hline
\end{tabular}

The mean of the actual concentration ratios is considerably larger than the mean of the estimated two minimum efficient concentration ratios. This indicates that concentration is higher than is strictly required for production efficiency.

In the second step the relationship between market size and the minimum efficient size of the firm is estimated for the eleven countries. Figures $4 a, 5 a$, and $6 a$ show the results for the different definitions of the minimum efficient firm size (according to table 3 ) for life/ health insurance. Figures $4 \mathrm{~b}, 5 \mathrm{~b}$, and $6 \mathrm{~b}$ show the results for non-life insurance using the different measures of MES according to Table 4; and Figures $4 \mathrm{c}, 5 \mathrm{c}$ and $6 \mathrm{c}$ for the total insurance market, respectively.

Fig. 4a: MES I (Life insurance) and Market Size

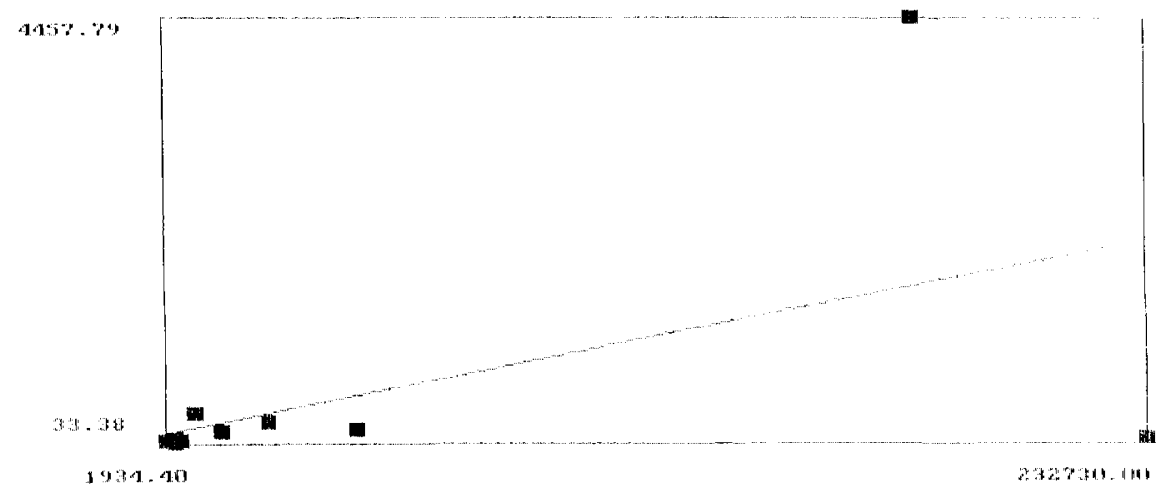


Fig. 5a: MES 2 (Life Insurance) and Market Size

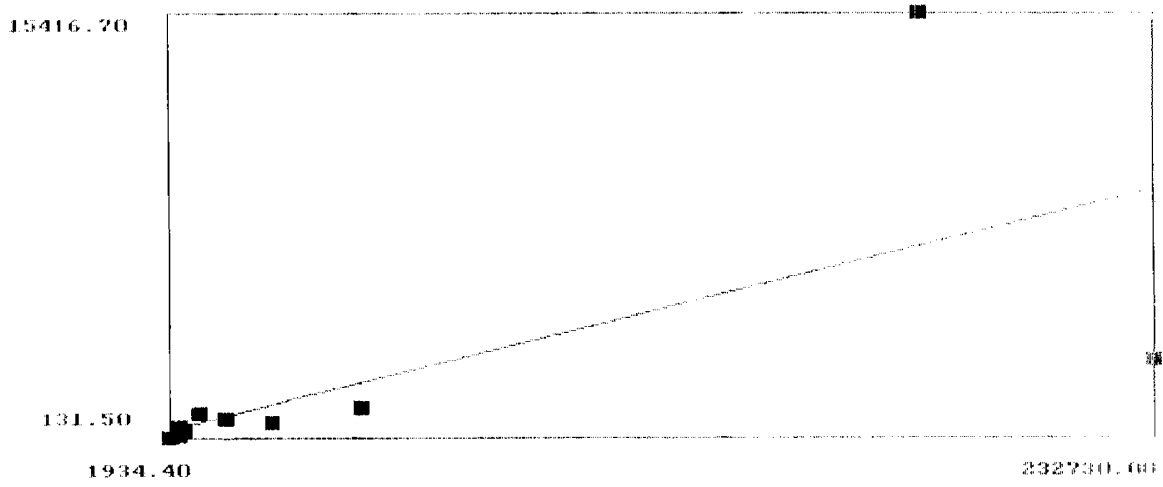

Fig. 6a: $\mathrm{MES}_{3}$ (Life Insurance) and Market Size

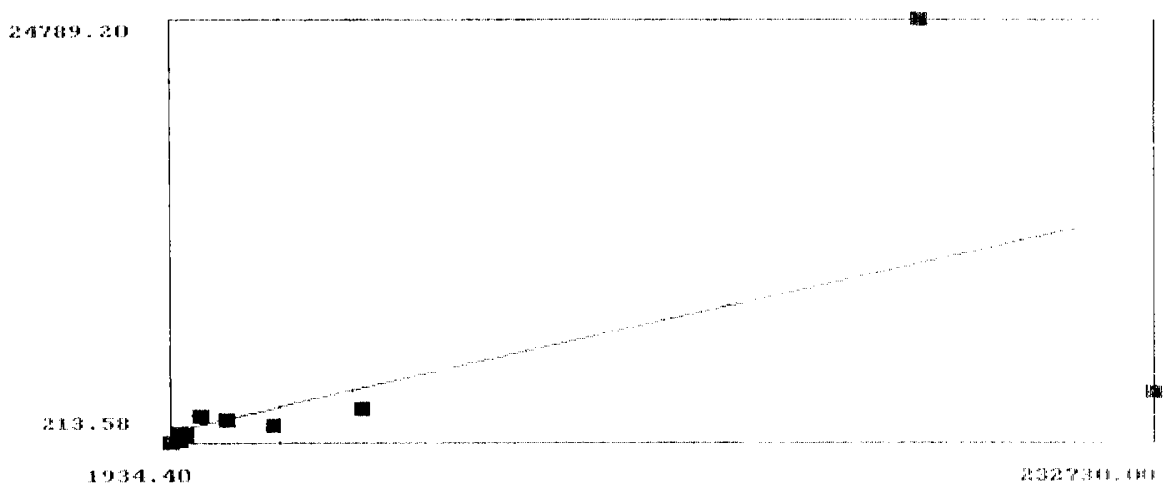

Fig. 4b: MES 1 (Non-Life Insurance) and Market Size

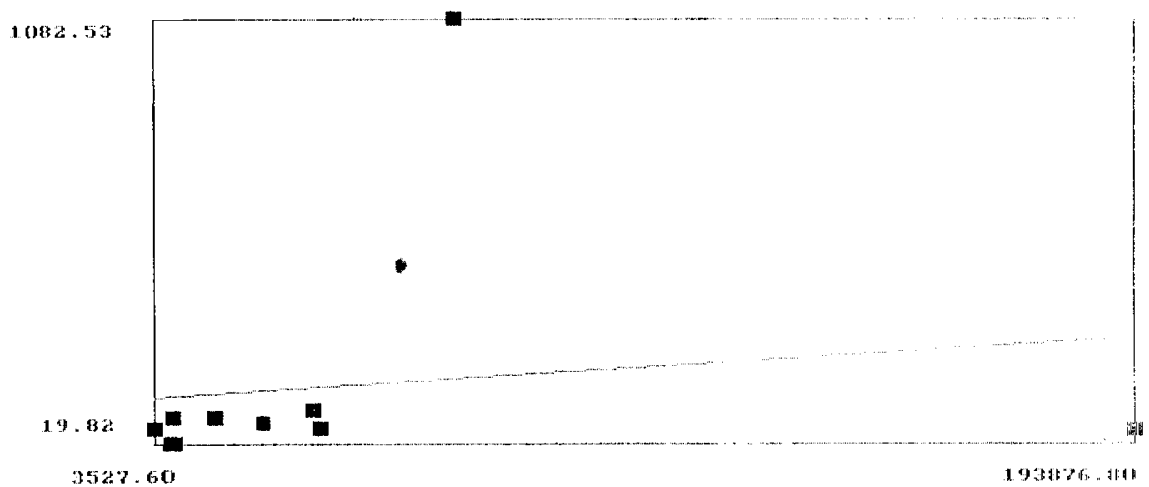


Fig. 5b:MES 2 (Non-Life Insurance) and Market Size

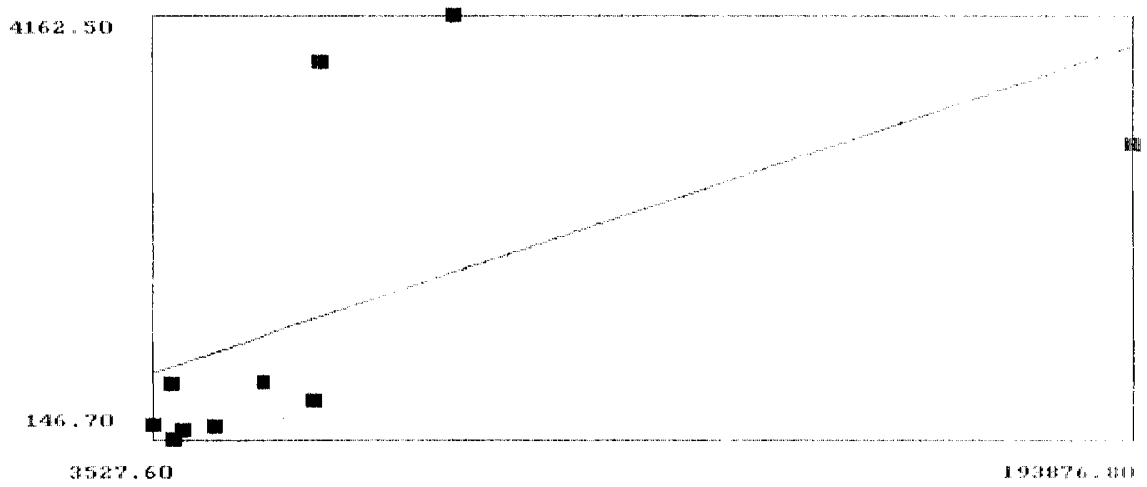

Fig. 6b: MES 3 (Non-Life Insurance) and Market Size

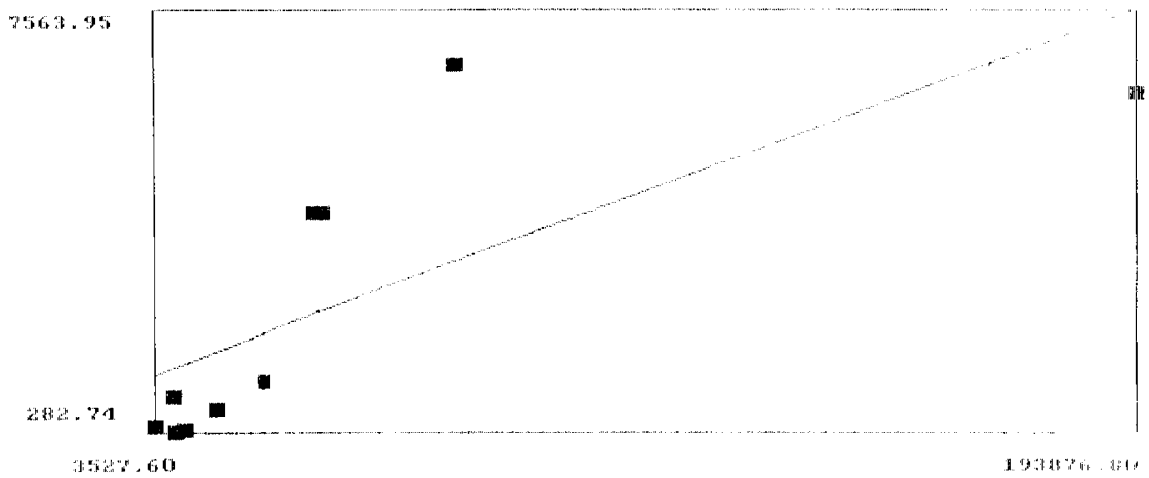

Fig. 4c: MES I (Life and Non-life) and Total Market Size

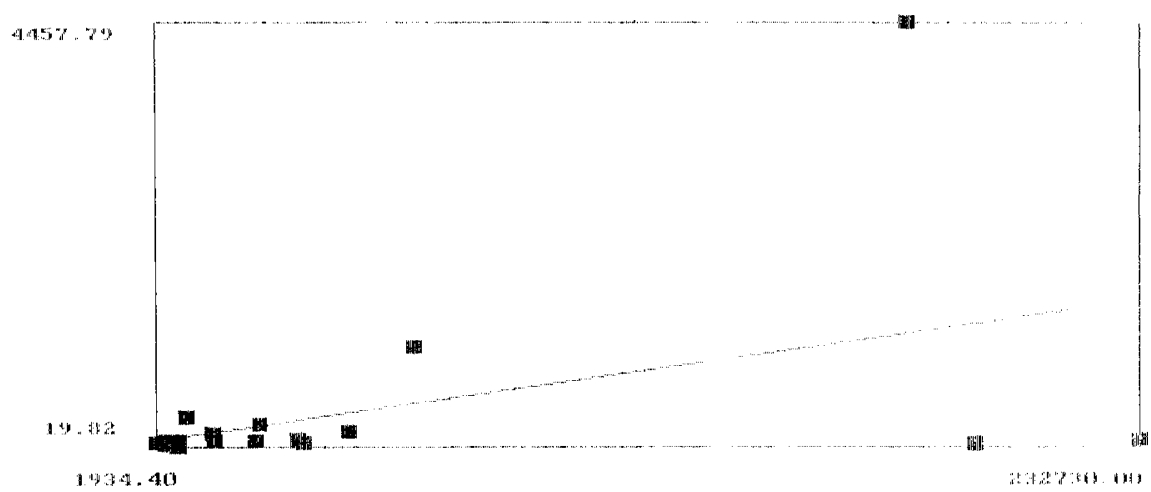


Fig. 5c: MES 2 (Life and Non-life) and Total Market Size

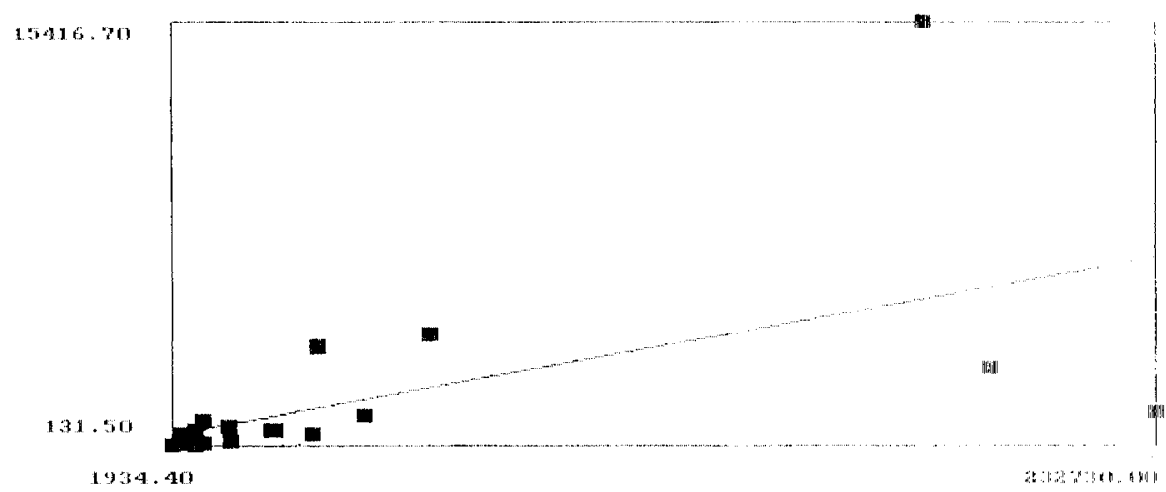

Fig. 6c: $\mathrm{MES}_{3}$ (Life and Non-life) and Total Market Size

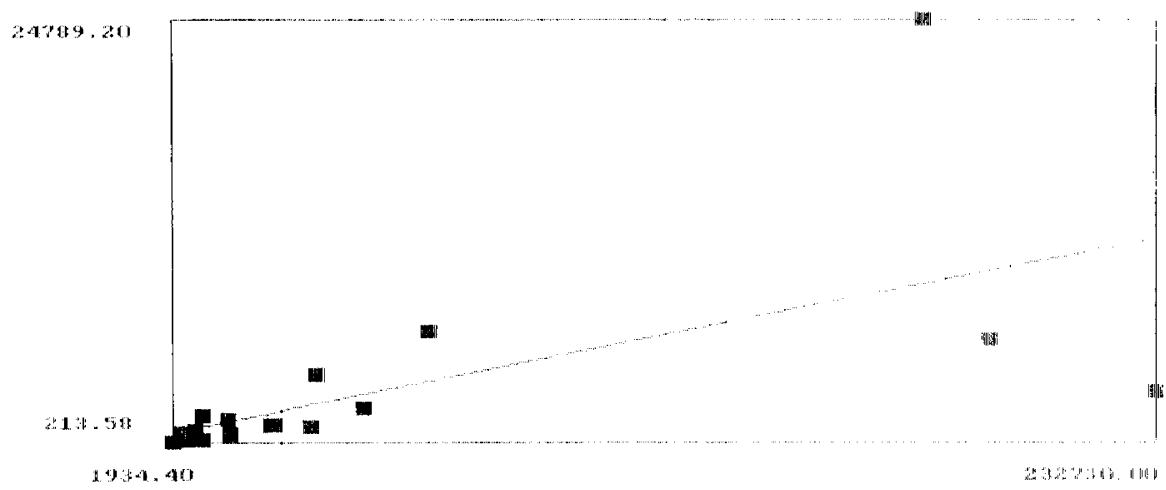

The results show always a clear positive relationship between market size and minimum efficient firm size. The "best fits" are obtained for life insurance with $\mathrm{MES}_{3}(\mathrm{R}$-squared = .3823 ; adjusted $\mathrm{R}$ - squared $=.3136)$, and non-life insurance with $\mathrm{MES}_{3}$ ( $\mathrm{R}$ - squared $=$ .5704 ; adjusted $\mathrm{R}$ - squared $=.5167) .{ }^{6}$

In a third step I have correlated the number of firms (S/MES 1$)$ and the market size (S) for the eleven countries. According to the hypotheses concerning average costs and the behaviour of the insurance firms mentioned at the end of the proceeding chapter it results that larger markets typically have a larger number of firms. Figures $7 \mathrm{a}, \mathrm{b}, \mathrm{c}$ show the results.

${ }^{6}$ I thank Stephen Diacon for pointing out that the OLS estimation may be unduly influenced by a few extreme observations (Japan and/or U.S.A.). In the OLS regression analysis the data are, therefore, corrected for heteroscedasticity. 
Fig. 7a: S/MESı (No. of Firms in Non-life) and Market Size (S)

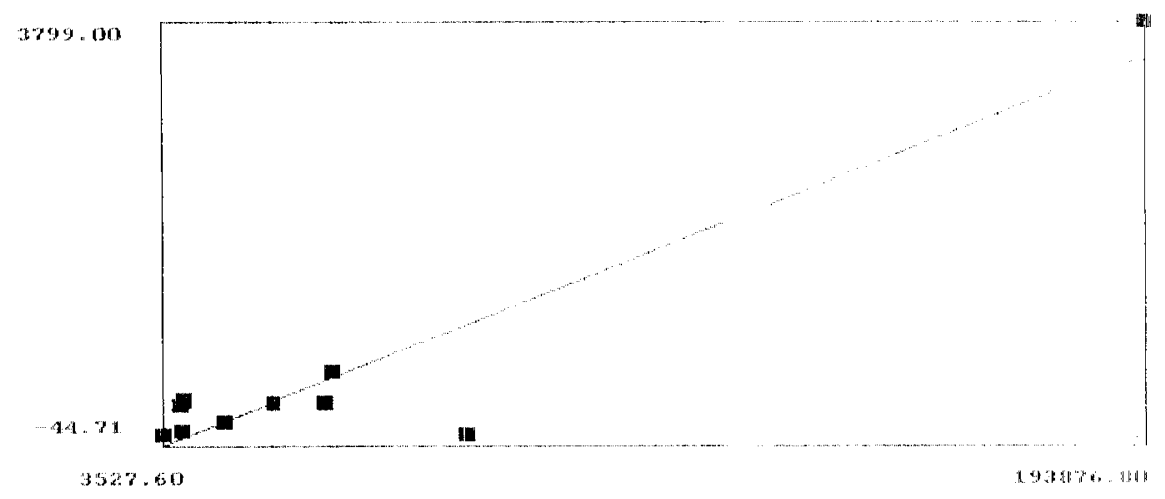

Fig. 7b:S/MES। (No. of Firms in Life) and Market Size (S)

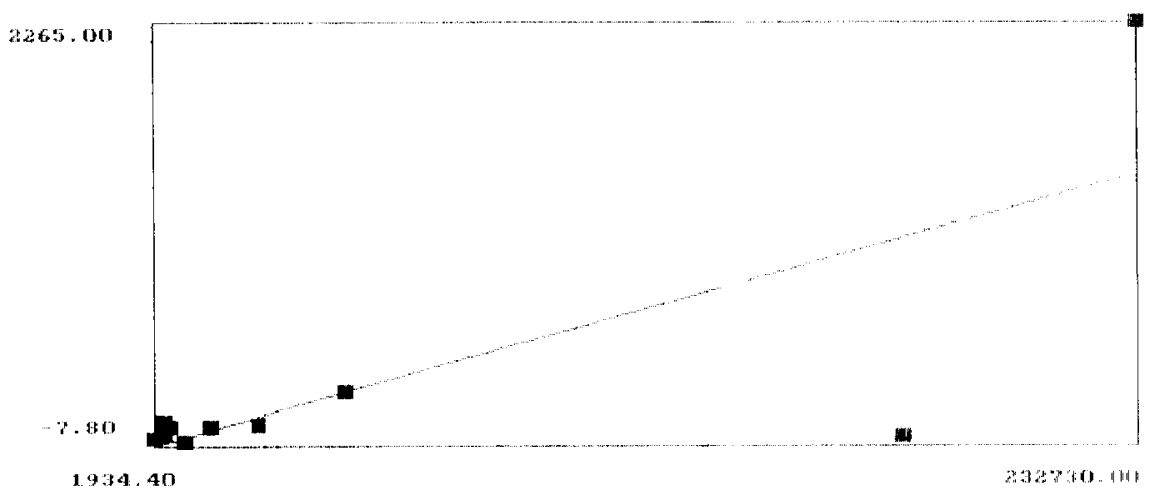

Fig. 7c: S/MES I (No. of Firms in Life and Non-life) and Total Market Size (S)

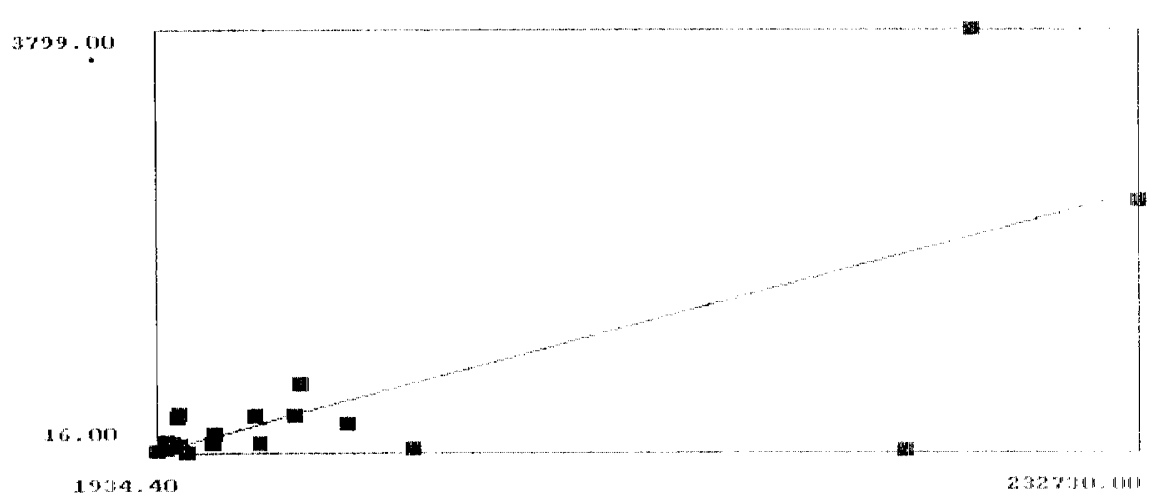


The correlation is always positivc and very strong for non-life insurancc and the total insurance market $(\mathrm{R}-$ squared $=.8812$; adjusted $\mathrm{R}$ - squarcd $=.8663)$.

\section{Summary and conclusions}

It is appropriate to precede the conclusions with a note about the limitations of the kind of exercise that $l$ have undertaken here.

First of all, I have not (really) tested for cconomics of scale; the function tested is too simple. But using other output measures or more complicated functional forms are also subject to serious questions rcgarding product homogeneity, vertical integration, production technology, and quality of outputs. Furthermore, the evidence of economies of scale and scope in the literature is ambiguous, the best guess seems to be that beyond the (real) MES of firms, long-run average costs are constant.

Second, the data 1 have used are somewhat restricted. It is a common practice for property-liability insurers to operate several associated insurers known as "groups". Therefore, it would be advisable to correctly assign individual insurers to their respective group, and to report the figures appropriately. The astonishing large figures for the United States would then be more reasonable ( 800 groups instead of almost 4000 insurers).

Third, I have applied a piece of Industrial Economics to the insurance industry - and the extent in how far this is admissible seems questionable. This relates (a) to the concept of the minimum efficient scale itself developed for "plant size" and not "firm size". It concerns (b) the use of net premium, i. e. gross premium income minus reinsurance. Would it not bctter to use gross premium? Gross premium income determines the firm size, especially when measured by employment figures. But that involves the problem of the degree of vertical integration.

Nevertheless, the main conclusions are the following: First, also in the insurance industry firm sizes are on average larger in larger markets. This is so whether MES $1, \mathrm{MES}_{2}$, or MES 3 is used as measures of optimal firm size. The best results are obtained with the Top $50 \%-$ lndex for life/health insurance and non-life insurance. As a consequence, European Insurance companies are considered to be - on average - too small, suffering a competitive disadvantage with respect to their American or Japanese counterparts.

Second, the relationship between actual concentration ratios and minimum cfficicnt scale concentration ratios points out that insurance markets show higher concentration than is necessary from an efficiency standpoint.

Third, if the insurance industry is characterized by constant returns to scale over a widc range of output, a rightward shift of the dcmand curve for insurance coverage will result in both ncw cntry and growing firm size of incumbents although the slope of the (avcragc) cost curve does not restrict firm size. The results shown in Figures 7 a-c indicate that also the (optimal) number of insurance firms grows with market size.

Fourth, in general firm size deviations from MES cxist mainly because markets in the $\mathrm{EC}$ are too small in relation to MES. Trade barriers and different regulatory schemes hinder the extension of markets. 
Now, it is gcnerally expccted that with the completion of the European Internal Market at the end of 1992 existing gaps betwecn current and efficicnt firms sizes will diminish over time. If no regulatory or non-tariff barriers hinder trade and service flows between national markets, producers' choice of firm sizes may bc less limited, Icading to an adjustment process towards larger firms, and, conccquently, toward a fuller exploitation of economies in production and trade. This structural change, howcver, will not take placc overnight. At the least, this process may bc hindercd by languagc barricrs and differences in mentalities - leading to the saying that "all business is local business". Two other types of official barricrs still matter, however: tax and currency diffcrences. This in turn may mean that the averagc sizc of insurance companics in the EC falls short of the possible or efficient size for a rather long period of time.

Outside the scope of the present study arc, however, the following queries: First, an evaluation of the likcly response of (individual) insurance firms in different countries to the assumed single market; and second, an evaluation of the likelihood of progress towards an integrated Internal Insurance Market, and the regulation which will (eventually) prevail. And there are signs which indicate that the Commission of the European Communities will exclude forms of cooperation arrangements from the prohibition of cartels via "block exemption regulation". However, to describe these fears would be another paper (but see Eisen/Müller/Zweifel, 1990 b).

\section{BIBL.IOGRAPHY}

APPEL, D., et al. (1985), Survivorship and the Size Distribution of the Property-Liability Insurance Industry, Journal of Risk and Insurance 52, 424-440.

BAUMOL, W. J., et al. (1982), Contestable Markets and the Theory of Industry Structure, New York et al.

BRAEUTigAM, R. R., and PAULY, M.V. (1986), Cost Function Estimation and Quality Bias: The Regulated Automobile Insurance Industry, Rand Journal of Economics 17, 606-617.

COMANOR, W. S., and WILSON, T. A. (1967), Advertising, Market Structure and Performance, Review of Economics and Statistics 49,423-440.

Commission (1985) of the European Communities, Completing the Internal Market, White Paper from the Commission to the European Council, Luxembourg.

CUMMINS, D. and VANDERHEI, J. (1979), A Note on the Relative Efficiency of Property-Liability Insurance Distribution Systems, Bell Journal of Economics 10, 709-719. 
DAVIES, S. (1980), Minimum Efficient Size and Seller Concentration: An Empirical Problem, The Journal of Industrial Economics 28, 287-301.

DAVIES, S. W., and LYONS, B. R. (1982), Seller Concentration: The Technological Explanation and Demand Uncertainty, Economic Journal 92, $903-919$.

DOHERTY, N. (1981), The Measurement of Output and Economies of Scale in Property-Liability Insurance, Journal of Risk and Insurance 48, 390-4(12.

EISEN, R., MÜLLER, W., and ZWElFEL, P. (1990 a), Unternehmerische Versicherungswirtschaft, Wiesbaden.

EISEN, R., MÜLLER, W., and ZWEIFEL, P. (1990 b), Dangers of Delegated Regulation: The Case of the EEC and Insurance, World Competition 14, 7-18.

EMERSON, M. et al. (1988). The Economics of 1992. The E.C. Commission's Assessment of the Economic Effects of Completing the Internal Market, Oxford.

FINSINGER, J. (1983), Versicherungsmärkte, Frankfurt a. M., New York.

FRECH H. E., 111 (1980), Health Insurance: Private, Mutuals, or Government, in: Economics of Nonproprietary Organization, Research in Law and Economics, Suppl. 1, 61-73.

FRECH, H. E., 11 and SAMPRONE, J. C. Jr. (1980), The Welfare Loss of Excess Nonprice Competition: The Case of Property-Liability Insurance Regulation, Journal of Law and Economics XX111, 429-440.

GEROSKI, P. A. (1988), Competition and Innovation, chapter 6, in: European Communities - Commission (ed.), Research on the "Cost of Non-Europe"- Basic Findings, vol. 2 - Studies on the economics of integration, Document, Luxembourg.

MARSHALL, J. M. (1974), Insurance as a Market in Contingent Claims: Structure and Performance, Bell Journal of Economics 5, 670-682.

OUTREVILLE, J. F. (1987), Concentration et Economies de Dimension dans l'Assurance: Revue de la Littérature et Situation Actuelle, mimeo.

PASHIGlAN, P. (1969), The Effect of Market Size on Concentration, International Economic Review 10, 291-314.

PESTIEAU, P., and PIRARD, Ch. (1989), L'entreprise d'assurance: économies d'échelle et performance, Revue d'Economie Financière No. 11, 93-104.

Price Waterhouse (1988), The "Cost of Non-Europe" in Financial Services, in: European Communities - Commission, Research on the "Cost of Non-Europe" - Basic Findings, vol. 9, Luxembourg.

SCHERER, F., et al. (1975). The Economics of Multi-Plant Operation: An International Comparison Study, Cambridge/Mass.

Swiss Reinsurance (1989), Insurers’ Market Shares in 12 Countries, Sigma, Economic Studies 2.

WEISS, L. (1963), Factors in Changing Concentration, Review of Economics and Statistics, 45, 70-77.

WEISS, L. (1964), The Survival Technique and the Extent of Sub-Optimal Capacity, Journal of Political Economy 72, 246-261.

ZWElFEL, P., and GHERMl, P. (1990), Exclusive vs. Independent Agencies: A Comparison of Performance, Geneva Papers on Risk and Insurance 15, 171-192. 